\title{
Subsidizing Equality: Female Candidate Emergence and Clean Elections
}

\author{
David L. Wiltse
}

\begin{abstract}
A lack of gender parity amongst candidates for public office is of perpetual concern to political reformers. One reform that is suggested as a partial solution is the full public subsidy of election costs. In theory, "clean election" laws should dramatically lower the perceived costs of campaigns to potential candidates outside of traditional fundraising networks. If the perceived costs are lowered to a significant enough degree, public subsidies could encourage more women to run for office. Using panel data of potential candidates from Connecticut and Massachusetts, this article finds that the Citizens' Election Program may have led to some progress towards that goal. However, women's emergence decisions and attitudes concerning fundraising are more dependent upon active recruitment by civil society organizations and political parties, factors well beyond the reach of clean election laws.
\end{abstract}

Keywords: clean elections, campaign finance, candidate emergence

\section{INTRODUCTION}

A PERPETUAL CONCERN AMONGST AMERICAN political reformers is a dearth of women seeking elected office (Carroll and Sanbonmatsu 2013). Despite some modest, sporadic gains, parity in either election to office or candidate emergence remains elusive. One institutional reform that is often suggested as a remedy is public subsidies to candidates aimed at dramatically lowering the costs of campaigns, thus freeing people's time and energy from fundraising activities. On its face, this makes a great deal of sense. It is widely acknowledged

David Wiltse is an assistant professor in the Department of History, Political Science, Philosophy, and Religion at South Dakota State University in Brookings, South Dakota. Funding for this research was provided by the JEHT Foundation and National Science Foundation (Grant No. 0924421). Professor Wiltse would like to thank Lisa Hager, Ray La Raja, Alison Dagnes, Jim Gimpel, David Davis, Kathryn Ust, Kuo-Liang Chang, and Evren Celik Wiltse for various support. Sincere gratitude is also owed to the editor and anonymous reviewers. that candidates and office holders generally dislike fundraising and the large amount of time that must be dedicated to the task. Moreover, in the cases of candidates who come from outside the traditional party and fundraising networks, as female candidates often do, public financing is an effective way of lowering the amount of time a candidate must spend "dialing for dollars" (Francia and Herrnson 2003). Should the perceived costs of the election (literal monetary costs, plus encumbrances of time, energy, etc.) be lowered to a significant enough degree, public subsidies could well encourage more women to emerge as candidates.

Scholars who have examined candidate emergence generally take a "strategic candidate" frame of analysis (Black 1972). Utility models of candidate ambition that include perceived costs of running alongside strategic assessments find that these costs are an integral part of the decision to run for office and that there are differences in the way in which women take this decision compared to their male counterparts (Maestas et al. 2006). We also know that women tend to be more concerned about campaign finance than 
are men, and will use more of the available techniques to raise money (Jenkins 2007). Understandably then, in states that offer public subsidies, women are more likely to participate in these programs relative to men (Werner and Mayer 2007). Taken together, these works suggest that the cost perceptions of potential candidates (PCs) are different between men and women. What is unanswered, though, is whether the adoption of campaign subsidies has a significant impact on the emergence calculus of women relative to men.

To answer this question more fully, the data used in analysis must meet two important conditions. First, we must be able to observe the behaviors of people who forego a run, not just those who qualify for the ballot. Second, we must be able to observe these same potential candidates across timebefore and after the introduction of public subsidies. To date, most considerations of the emergence calculus of candidates were wanting in either, or both, of these conditions, particularly the latter. However, panel data from Connecticut that spans the implementation of that state's Citizens' Election Program (CEP) allows us to do just that (La Raja and Wiltse 2015a). Attitudes and behaviors of potential candidates, before and after the "treatment" of full public subsidies, can be measured, allowing us a more complete picture of how this program affects their consideration for a run to the state legislature. The results in this article suggest that the adoption of clean elections may have had some positive effect on encouraging the emergence of female candidates, yet it did little to change their attitudes on their ability to fund their campaigns. Moreover, in the final analysis, the effects of clean election reforms are clearly subordinate to strategic concerns and relational factors unrelated to public subsidy.

\section{PUBLIC FINANCING AND CANDIDATE EMERGENCE}

The assumptions that reformers make on the efficacy of public financing as a means to increase the number of female candidacies rest in strategic candidate theory. Black (1972) demonstrates that potential candidates use a simple utility function whilst considering a run for office, $\mathrm{u}(\mathrm{O})=(\mathrm{PB})-\mathrm{C}$, where:

$\mathrm{u}(\mathrm{O})=$ the utility of an office prior to the election $\mathrm{P}=$ the candidate's estimate of the probability she can obtain office
$\mathrm{B}=$ the benefit that an individual will receive from holding office

$\mathrm{C}=$ the cost required to attain office

Black's focus on the structural aspects of the calculus, specifically those that affect the probability of winning, suggest that there are important structural barriers that aspiring politicians must overcome as they seek office. Scholars that have focused on the effects of public financing laws have adopted this utility function (e.g., Miller 2013), as the effect of manipulating campaign costs are patent within the theoretical framework.

Clean election reforms that are aimed specifically at encouraging the entry of candidates from underrepresented groups would do so by reducing the costs of running associated with financing their campaigns. Yet, the campaign costs associated with a run for office go well beyond the literal costs of campaigning; though such costs are certainly of prime, strategic concern. Francia and Herrnson (2003) and Miller (2013) show that public financing systems may alleviate the costs associated with time spent in the money chase, provided they cover the full costs of campaigns.

Until the implementation of "clean elections" laws in Arizona and Maine in 2000, Minnesota and Wisconsin had the most generous systems of public funding for state legislative races. The subsidies offered in those states are often referred to as "partial" since they were not designed to subsidize the full costs of an individual campaign. The programs were adopted in 1974 and 1977, respectively, in the wake of the Watergate scandal and the Federal Election and Campaigns Acts. ${ }^{1}$ Though there were some differences in the allocation structures of the subsidies, the mechanics and scope were similar. In both states, candidates could accept public funding conditioned on raising qualifying funds and abiding by spending limits. Candidates that took full advantage of the subsidy could have had up to half of their campaign costs covered by the state (Donnay and Ramsden 1995; Mayer and Wood 1995).

Minnesota's system, while still intact and enjoying high levels of participation, comes nowhere near the generosity of clean election models. Party nominees for the House, after reaching a qualification threshold of $\$ 1,500$ in contributions (of which

\footnotetext{
${ }^{1}$ Wisconsin repealed its program in 2011.
} 
only the first $\$ 50$ of an individual contribution may apply), can receive up to 50 percent of the spending limit in subsidy, receiving their first subsidy distribution shortly after winning the primary. The threshold for candidates to the state senate is $\$ 3,000$. In the 2014 election cycle, of the $\$ 7,495,499$ spent by candidate committees for the House of Representative races, $\$ 1,071,116$ of that was from the public subsidy. ${ }^{2}$ Money raised through individual contributions, political action committee (PAC) contributions, and other traditional private sources constitutes the balance of funding. Thus, candidates must still spend considerable time in traditional fundraising efforts. Moreover, candidates do not receive any subsidy prior to securing the nomination, possibly limiting the public funding system's effect on the emergence calculus of a PC early in the election cycle.

The hopes of reformers hinged upon the prospect that public funding would sufficiently reduce the C-term of a PC's emergence calculus, thus raising the numbers of legislative candidates and increasing electoral competition. Though participation levels in Minnesota remain fairly strong in legislative races, the critical question is whether the subsidy substantially changes the cost perceptions of potential candidates enough to affect their emergence calculus. Research on these systems strongly suggests that it has not. One reason is because the partial subsidies are insufficient to overcome the fundraising advantages of incumbents (Mayer and Wood 1995). Perhaps more important to the discussion here, Miller (2013) notes that, "partially funded candidates will likely have a day-to-day campaign experience that is little different from that of candidates accepting solely private funding" (33). Thus, costs associated with fundraising will remain high in the minds of PCs. Moreover, the acceptance of these subsidies strictly limits the amount of spending and fundraising opportunities candidates are afforded, potentially placing substantial strategic costs to those who accept the subsidy (Mayer and Wood 1995). Put differently, these partial funding laws may act as a double-edged sword: while they may alleviate some costs in running by lowering the C-term, they can simultaneously drive down the P-term if a candidate expects a race will exceed the spending limit, thus negating the intent of the subsidy.

The first clean election law for legislative candidates was enacted in Maine through a public initiative in 1996, following what Schneider (2000) characterized as a reform movement spurred by the high costs of Maine's 1994 gubernatorial race and unflattering disclosures between special interest groups and legislators in the 117th and 118th legislatures. As a sign of the intensity of its supporters, the initiative gathered more than the requisite number of signatures-approximately 65,000 - in a single day. The measure passed by a 56 to 44 margin. The reforms were implemented in the 2000 cycle. Nearly two decades later, the system's funding was increased by public initiative in 2015 by a 55 to 45 margin, suggesting that it retains a good deal of popularity. Arizona followed suit with a popular initiative in 1998. The socalled "AzScam" scandal of 1991 that resulted in seven indicted legislators, the resignation of 10 percent of the legislature, and the conviction of Gov. Fife Symington on multiple felony counts, is often credited with creating an atmosphere receptive to these sweeping reforms (Pont and Pollock 2014; Spencer 2012). Connecticut's clean election law was passed in 2005. Like Arizona, the law came in the wake of the conviction of the state's governor, John Rowland, on various corruption charges. Unlike the experiences in Maine or Arizona, the law originated in the legislature and was signed by Rowland's successor Jodi Rell. Only three other states have seriously considered similar reforms. ${ }^{3}$

The clean election subsidy is far from "free," however. In the interest of preventing politically marginal candidates from receiving state support and keeping the overall costs to the state under control, candidates must raise seed money to prove electoral viability. Arizona requires 250 donations of $\$ 5$ to receive the subsidy for house elections. Connecticut has a much higher threshold of $\$ 5,000$ in aggregate contributions, but gives more flexibility in that

\footnotetext{
${ }^{2}$ As per the Minnesota Campaign Finance and Public Disclosure Board (2015). Minnesota has a tiered system of limits ranging from a base of $\$ 63,100$ to $\$ 83,292$, with bonuses for first-time House candidates, candidates with closely contested primaries, or both. This limit is inclusive of monetary expenditures, in-kind expenditures, and unpaid campaign expenditures. Limits for Senate candidates range from $\$ 94,700$ to $\$ 125,004$. In 2010, Wisconsin's final year of public funding, the total spending limit for a state assembly race was $\$ 17,250$ with a maximum subsidy of $\$ 7,763$ (Wisconsin Government Accountability Board), with the mean cost of assembly races at $\$ 27,717$ (National Institute for Money in State Politics).

${ }^{3}$ In 1998 Massachusetts voters passed a clean election law by a nearly two to one margin. However, the legislature refused to fund the measure, and ultimately repealed the measure in 2003. California has had similar initiatives rejected in 2006 and 2008, as has Alaska in 2008.
} 
qualifying contributions may range from $\$ 5$ to $\$ 100$. Maine's is perhaps the easiest, with 60 contributions of $\$ 5$ or more required for qualification. Miller's (2013) interviews with candidates have shown that many find this somewhat challenging. But as he characterized the general tenor of his respondents, "Most candidates recognize that as challenging as qualification was, fundraising would have been more difficult had they run as a traditional (privately financed) candidates." (34). Once the threshold is reached, candidates to the Connecticut state house are entitled to a grant of $\$ 11,260$ for the primary election and $\$ 28,150$ for the general election, conditioned on their spending being capped at the sum of the grants and their qualifying funds. ${ }^{4}$ This figure is adjusted in each election cycle to meet the expected overall expenditures of a candidate's primary and general election. In effect, the state is gifting about $87 \%$ of the total campaign costs, a much higher proportion than the system found in Minnesota. The grant amounts in Maine and Arizona are also set to meet a similar proportion of campaign costs.

As constructed, the election laws adopted in Arizona, Maine, and Connecticut deliberately attempt to ameliorate the shortcomings of existing partial public subsidy schemes by unambiguously driving down the C-term of the PC's emergence calculus, without lowering the P-term. By providing a subsidy of the average cost of an election, the overall cost estimation on the part of the potential candidate would presumably be affected to a much greater, positive degree in a clean election state than a partially funded state, without the concurrent strategic concerns of being dramatically outspent by one's opponent. The PC would no longer have to work nearly as long or as hard for a fully funded campaign, nor would she have to worry about being strategically bounded by spending limits set below the projected cost of the average campaign. ${ }^{5}$

The effects of subsidies should have varying degrees of effectiveness dependent upon the level of office. Dowling (2011), in his analysis of gubernatorial races, found that the effects of public financing are apparent only in cases of experienced incumbent party candidates running for an open seat. Though these effects are at best modest, it shows that "public financing is not entirely inconsequential to candidate participation..." (199). There is however, good theoretical reason to suspect that the effects of public financing on candidate entry would be more profound as we look towards lower levels of office. Candidates for state legislature, particularly the lower chambers, are more likely to be neophytes than those for higher office, thus lacking many of the important connections to financial constituencies. Indeed, Hamm and Hogan (2008) found that stringent contribution limits encouraged more inexperienced candidates to emerge when incumbent finances were more constrained. Additionally, Werner and Mayer (2007) found that candidates for the upper chambers of their respective legislatures were less likely to accept public grants than lower chambers. Moreover, the overall advantages of incumbency, particularly in a semi-professional legislature like Connecticut's, are weakest at these lower levels of office (Berry, Berkman, and Schneiderman 2000). Given these findings, the ideal level of analysis for assessing the cost-reducing effects of public financing on candidates' emergence calculus would be at this entry level.

Full election subsidies have the potential to affect the P-term of the calculus as well. We know from past work on emergence that these strategic concerns are of prime importance to PCs as they form their ambitions of holding office, particularly their perception on the probability of winning (Bianco 1984; Jacobson and Kernell 1981; Maestas et al. 2006), and incumbent vulnerability (Krasno and Green 1988; Lazarus 2008). An increasing amount of scholarly attention is being focused on how public financing affects the degree of competition. Experimental work of Panagopoulos and Green (2008) suggests that "even-handed campaign finance laws can enhance electoral competition" (166). Donnay and Ramsden (1995) found that Minnesota's partial subsidies do in fact raise the level of competition in the state's elections, but caution that public money helps incumbents, not just challengers. Others, focusing more specifically on clean election laws, find that competitiveness and the likelihood of a major party challenger are indeed higher in clean election states (though not necessarily challenger success), primarily from the reduction of uncontested elections and

\footnotetext{
${ }^{4}$ As per the State Elections Enforcement Commission's 2016 Election Program Overview.

${ }^{5}$ In Connecticut prior to the 2012 elections, candidates were eligible for up to three times the grant if they were outspent by an opponent. This provision would address these same strategic fears of being outspent by privately funded candidates. However, this type of provision was found unconstitutional in the case McComish v. Bennett 10-239 (2010).
} 
reducing key advantages of incumbency (Hamm and Hogan 2008; Malhotra 2008; Mayer, Werner, and Williams 2006).

Taken as a whole, the extant literature provides solid theoretical grounds and a degree of empirical evidence to suspect that full election subsidies could alter potential candidates' utility calculus enough to encourage more candidates to emerge. Most obviously, the subsidy is structured in a way that the $\mathrm{C}$-term is radically reduced. Yet perhaps just as importantly, the P-term is less likely to be moved. The critical shortcoming of the partial subsidies offered in Minnesota and Wisconsin-the funding and spending limitations of accepting the grant-has not been seen in the clean election states. As Malhotra characterized those states, "only rarely will a candidate [that accepts the grant] will be outspent" (267).

Yet there are reasons to be skeptical. First, when we compare the rates of female representation in state legislatures throughout New England, it is difficult to see stark differences between the clean election states of Maine and Connecticut and the traditionally funded states of Rhode Island, Massachusetts, Vermont, and New Hampshire (Figure 1). Only in the state of Vermont, which traditionally leads the nation in the proportion of female legislators, do we see what could be described as sustained improvement towards gender parity in the state legislature. The trend lines for both Maine and Connecticut, as well as the other New England states, are rather flat. The implementation years of clean elections are marked in both Connecticut and Maine. Though there is an increase in female legislators in the election following implementation in both states, it is hardly durable. In each instance, we see drops in the succeeding election cycle, with cycle to cycle variation on par with their neighbors in succeeding years.

La Raja and Wiltse (2015b) give us a second reason to be skeptical. Utilizing panel data from Connecticut (with Massachusetts as a control), they found that the utility calculus amongst Connecticut's potential candidates writ large was virtually unchanged at points before and after the implementation of the Citizens' Election Program. Strategic concerns were clearly the most important factors amongst their survey respondents. Referencing Mayer (2013), they posit that clean election reforms amount to a procedural change and do not provide for a broad enough systemic change to "shock" the cost calculations of potential candidates enough to change their behav- iors. Importantly however, they leave open the question of how these reforms might affect the behaviors and attitudes of certain subsets of potential candidates, particularly underrepresented groups such as women, whose emergence calculus might be different from men. While the numbers of women being elected might not be rising, there is the possibility that women's attitudes on emergence could be positively affected by the policy change. This question can only be answered through a systematic, multivariate analysis of a potential candidate survey.

\section{WOMEN, EMERGENCE, AND CAMPAIGN FINANCE}

As candidate emergence theories have been developed and refined over the past decades, scholars have taken special note of the various factors that have disproportionately affected female candidate emergence. These range widely from informal and formal structures at the macro level, down to individual level considerations of sociological and strategic factors.

Political structures, be they informal or formal, play an important role as they shape the playing field that political competition takes place in. Windett (2011) asserts that political ambition of women is dependent upon context. Some states have a "progressive female sociopolitical subculture" that that fosters women's emergence relative to traditional states. Directly related to this is the role of party and civil society recruitment. Researchers have demonstrated the importance of active recruitment in prompting individuals in running for office (Fulton et al. 2006; Maestas et al. 2006). Moreover, Fox and Lawless (2010) have shown that highly qualified female PCs are far less likely to be contacted by parties and other types of civil society organizations in their recruitment efforts, thus depressing emergence of women candidates. ${ }^{6}$ The effect of this type of contact is hardly gender neutral in terms of emergence. Carroll and Sanbonmatsu (2013) show that for women, the decision to

\footnotetext{
${ }^{6}$ Fox and Lawless (2010) show that women do not require "more frequent or more elaborate recruitment," than men to encourage a run; women are just not being asked to run as often as men. As such, women's civil society organizations are beginning to address this gap with some success, though the effects from this strong bias still remain.
} 

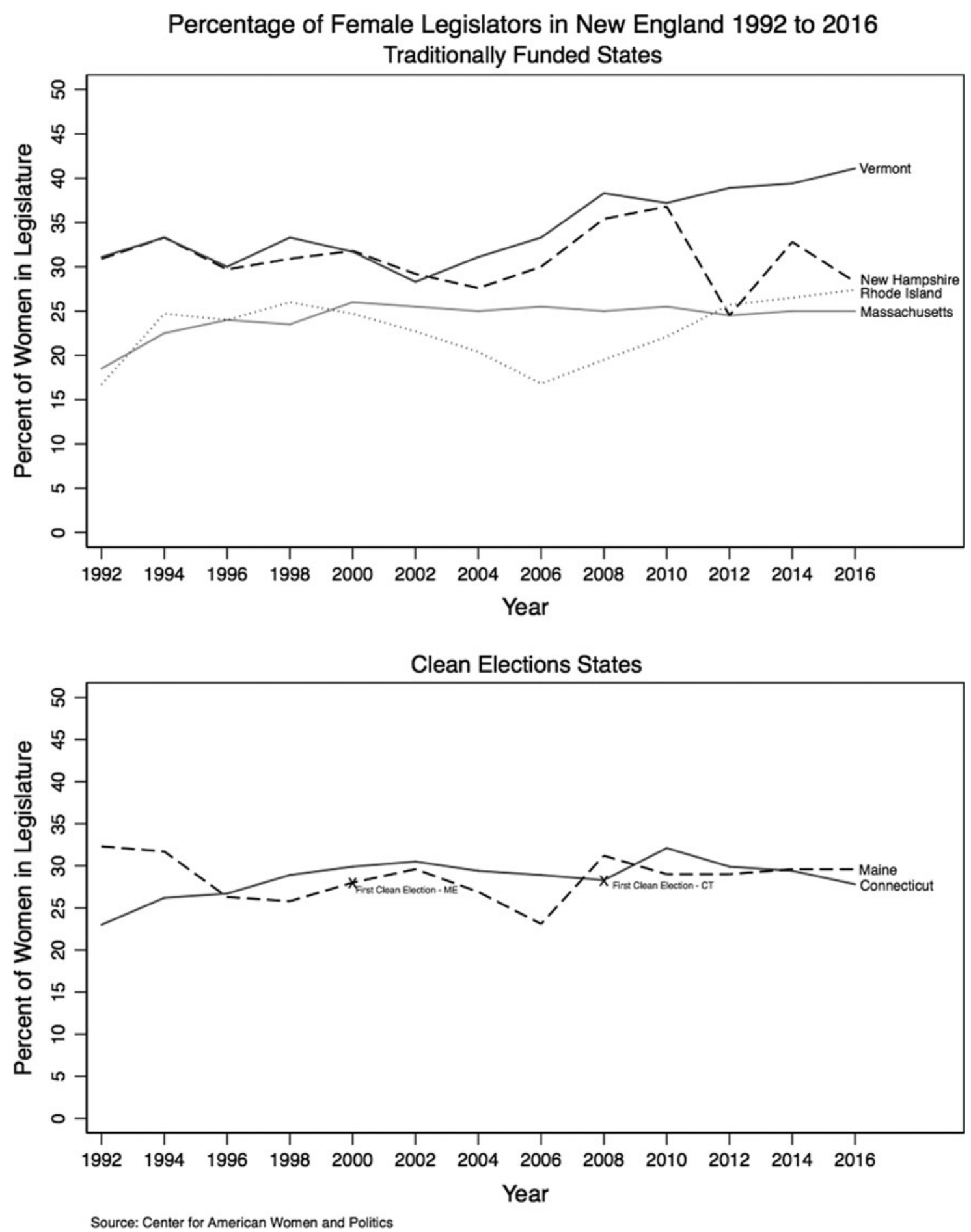

FIG. 1. Percentage of female legislators in New England, 1992 to 2016. Top panel: traditionally funded states; bottom panel: clean election states. Source: Center for American Women and Politics.

emerge is a "relationally embedded decision." Female state legislators in their survey indicated that encouragement from parties, political organizations, friends, and family is central to their decision; whereas men were more likely to be "self-starters," where nascent ambition was cited by respondents as driving their emergence decision. Formal political structures can have a decisive impact on women emerging as candidates. The primary process does not appear to be gender neutral (Lawless and Pearson 
2008), the costs associated with signature requirements can depress female emergence (Mitchell 2014), and multimember districts (by way of increasing competition) tend to drive up female emergence (Mitchell and Monroe 2014).

All this work points to inherent biases in the emergence process suggesting that women take this decision quite differently than men. Or, put in the terms of the emergence literature, women are showing different sensitivities to the various terms of the utility calculus relative to men. Fulton et al. (2006) characterize potential female congressional candidates (from their sample of state legislators) as "more responsive to expected benefits" relative to men, and thus "more 'strategic' with respect to their run decisions" (245). Differences arise in the weighing of costs as well. Maestas et al. (2006) show that both family costs and campaign costs are central to the emergence decision in the "selection phase" of candidacy. This, too, is gendered, as Fulton and colleagues (2006) show strong evidence that child care responsibilities drive up cost perceptions for women, but not men (241).

With evidence of a gendered emergence calculus clarifying, other determinants of this decision deserve greater scrutiny, particularly in instances where public policy could have a disproportionate effect on women. In many respects, this is a very clear intent of clean election laws. Reformers often trumpet the possibility that changes in the cost calculation of potential candidates might result in legislatures attaining higher levels of descriptive representation, as members of underrepresented groups may have less access to traditional fundraising networks. Research at the congressional level suggests that women are not disadvantaged in fundraising relative to men (Burrell 1994). However, at the levels of office where most candidates get their starts, such as state legislature, there is scattered evidence that women face a variety of challenges in fundraising relative to men (Carroll and Sanbonmatsu 2013; Lawless and Fox 2010; Thompson et al. 1998).

Female candidates have shown heightened awareness of campaign costs that could be directly affected by clean election laws. Using a survey of state legislative candidates, Jenkins (2007) shows that women are indeed more concerned about the costs of campaigns relative to men and pursue a wider degree of fundraising sources. In states that have "clean election" laws, Werner and Mayer (2007) found that women are more likely to accept public funding than are men in races to the lower chamber of the state legislature. In their comprehensive examination of female candidate emergence, Carroll and Sanbonmatsu (2013), using their national survey of state legislators, identified two key challenges women faced in fundraising: women not having the same networks as men and that women are less comfortable than men in solicitation of campaign funds. They summarize this discussion of campaign finance with clear statement of advocacy:

The perceptions we find here of an uneven playing field for women in the area of fund-raising suggest that one way to increase the number of women's candidacies might be for more states to adopt laws that make public funds available for state legislative races... the issue of money is not going away for women candidates and, if anything, is becoming a more important factor in their decisions about seeking office. (120)

Given these sentiments, it is clear that greater attention should be paid to possible differential effects of policies aimed at reducing campaign costs in the entry decisions of men and women.

In addition to the effects of policy, we must also consider the role of parties, civil society organizations, and non-political associates in addressing these financial concerns of PCs. The Candidate Emergence and Public Financing of Elections Dataset (CEPF) (La Raja and Wiltse 2015a) lends some empirical support to Carroll and Sanbonmatsu's claim that women are less likely to be actively recruited by partisan political organizations, and more likely to report candidacy encouragement from civil society groups (interest groups, service organizations, and professional organizations) and other non-political associates (friends, neighbors, coworkers). Table 1 presents the percentage of PCs that reported some kind of recruitment from each of these entities. In both waves of the survey, a statistically significant difference of about 11 percentage points was reported in partisan contacts between male and female PCs. The contacts of encouragement from civil society organizations were biased favoring women in 2009; and contacts from non-political entities were statistically indistinguishable between the genders in both years.

This raises important questions about how effective parties are in their outreach into the pool of women PCs. If the parties are systematically biased 
Table 1. Percentage of Potential Candidates

Recruited by Parties, Civil Society Organization, and Non-Political Entities

\begin{tabular}{lcccccc}
\hline & \multicolumn{2}{c}{ Party } & \multicolumn{2}{c}{$\begin{array}{c}\text { Civil } \\
\text { society }\end{array}$} & $\begin{array}{c}\text { Non- } \\
\text { political }\end{array}$ \\
\hline \multirow{4}{*}{ Women } & 2007 & 2009 & 2007 & 2009 & 2007 & 2009 \\
& $28 \%$ & $30 \%$ & $34 \%$ & $40 \%$ & $50 \%$ & $43 \%$ \\
Men & $(54)$ & $(31)$ & $(70)$ & $(42)$ & $(101)$ & $(46)$ \\
& $38 \%$ & $41 \%$ & $30 \%$ & $25 \%$ & $44 \%$ & $37 \%$ \\
Difference & $(162)$ & $(92)$ & $(128)$ & $(59)$ & $(189)$ & $(87)$ \\
\# Respondents & $617 * *$ & $11 \% * * *$ & $4 \%$ & $15 \% * *$ & $6 \%$ & $4 \%$ \\
$* * p|t|<.05$ two-tailed; $* * * p$ & $|t|<.01$ & 632 & 339 & 632 & 340 \\
\hline
\end{tabular}

in favor of men in recruitment, will there be a concurrent reduction in female PC ambition or their confidence in securing funds for a candidacy? We must also consider the countervailing effects that civil society and contacts have on the attitudes concerning political money and emergence amongst female PCs. If the parties are failing to reach out to women PCs effectively and alleviating their concerns about money, are interest groups, civil society organizations, and non-political entities providing effective supplemental support for women candidates in the parties' stead? Multivariate analysis of the potential candidate survey helps disentangle these divergent forces.

\section{DATA AND METHOD}

There are several shortcomings to the existing research on women's emergence in state legislative races, due almost entirely to the limitations of data. Many emergence surveys rely upon samples of either candidates or office holders. These leave out a critical subset of the population: those who have chosen not to run. Generally, these have focused on the emergence of candidates in the context of progressive ambition-those who seek higher office (i.e., state legislators who are considering a run for the U.S. House). To address this shortcoming, some survey work has been done on potential candidate pools independent of current office holding status. Maisel and Stone's Candidate Emergence Study (2003) utilized a "snowball" sample drawn from a list of potential candidates for the U.S. House through the use of informants-local politicos and activists-in 200 randomly selected congressional districts. Also at the national level, Lawless and
Fox $(2005 ; 2010)$ fielded a two-wave panel survey that sampled four professions that often act as a "pipeline" of potential candidates into any number of elective offices. However, neither of these surveys speak directly to how the emergence calculus of potential state legislative candidates might be affected by policy changes in any given state since the former is focused on PCs to the U.S. House and the latter on sampling PCs for a variety of elective offices nationwide. Additionally, there are few examples of panel studies that can track changes in attitudes and behaviors of the same potential candidates before and after comprehensive campaign finance reforms have been implemented.

The Candidate Emergence and Public Financing of Elections Dataset conducted in the states of Connecticut and Massachusetts (La Raja \& Wiltse 2015a) affords researchers a unique opportunity by surveying the same potential candidates to the state house before and after the implementation of clean elections. It is at this entry level that the effects of campaign finance reforms will likely be of highest impact on candidate emergence and where gender effects are most likely to show up (Carroll and Sanbonmatsu 2013; Werner and Mayer 2007). It draws heavily on the methods and instruments of Stone and Maisel's Candidate Emergence Study, with the additional goal to observe whether the "treatment" of the CEP in Connecticut affected the attitudes and behaviors of potential candidates to the state legislature.

The study utilized two methods of identifying potential candidates: a reputational approach and positional approach. The reputational approach asked political notables to identify people in their communities that would make for good candidates to the state legislature. These "informants" were selected amongst party, labor, and business organizations and other civic leaders based on the assumption that they are knowledgeable about politics in their locality, regardless of their own inclination to run. The positional approach tapped individuals in organizations where candidates for legislature traditionally emerge: town boards, school boards, labor unions, bar association, business groups, religious congregations, and civic organizations. Ultimately, $12 \%$ of respondents were chosen by the reputational approach, and $88 \%$ through the positional approach.

The first wave of the panel was sent in April 2007 to the list of potential candidates using a survey instrument very similar to Maisel and Stone's (1997). 
A total of 3,326 surveys were sent out, with 715 being returned (663 from Connecticut and Massachusetts $^{7}$ ), yielding a response rate of $21 \%$. Wave two of the panel was sent in April 2009 to the respondents that completed wave one, with 386 being returned-a response rate of 54\%. Demographically, the respondents of both waves were very similar, and were similar in composition to the Connecticut legislature (see Table 2). Regarding candidacy, $16 \%$ of respondents seriously considered a run in both waves of the survey, while $2 \%$ and $2.5 \%$ emerged as candidates in 2006 and 2008, respectively. ${ }^{8}$ The cultural and political similarities of the states abound, while the differences are as minimal as one could hope for in cross-state comparisons. ${ }^{9}$ One strength of the data is that it allows for the control of political culture, which is extremely hard to conceptualize and measure (Jackman and Miller 1996). ${ }^{10}$ By utilizing this panel survey, researchers can get purchase on previously unanswerable questions on the effects of "clean election" reforms.

To gauge the effects of clean elections and the emergence of candidates to state legislature, a series of multivariate analyses is conducted on different dependent variables of $\mathrm{PC}$ attitudes and behaviors that are associated with the emergence calculus. First, cross-sectional "base models" of ambition are estimated separately for men and women from wave one to test whether the two groups of PCs take the emergence decision differently, without specific consideration of Connecticut's CEP. These are sensitive to the theory of Maestas et al. (2006) that the deci-

Table 2. Respondent Demographics in the CEPF and Connecticut Legislature

\begin{tabular}{lcc}
\hline & $\begin{array}{c}\text { CEPF } \\
\text { Wave 1 }\end{array}$ & $\begin{array}{c}\text { Connecticut } \\
\text { Legislature 2009 }\end{array}$ \\
\hline Female & $32 \%$ & $32 \%$ \\
Non-white & $9 \%$ & $13 \%$ \\
Age & & \\
20-34 & $3 \%$ & $7 \%$ \\
$35-49$ & $20 \%$ & $25 \%$ \\
50-64 & $53 \%$ & $48 \%$ \\
65+ & $23 \%$ & $17 \%$ \\
Party affiliation & & \\
Democrat & $59 \%$ & $68 \%$ \\
Independent & $6 \%$ & $32 \%$ \\
Republican & $33 \%$ & \\
Residency & & \\
Connecticut & $47 \%$ & 187 \\
Massachusetts & $53 \%$ & \\
Number of cases & 663 & \\
\hline
\end{tabular}

$\overline{\mathrm{CEPF}}$, Candidate Emergence and Public Financing of Elections Dataset. sion to run is a two-stage process. First, a general interest in a legislative career develops in a PC; and second, the PC then makes the decision to enter a specific race based heavily on strategic considerations (e.g., timing, incumbency, etc.).

Utilizing the results of the base models as guides, a series of ordinary least squares (OLS) regressions are estimated with the panel data and several timevariant variables between the two waves of the survey amongst respondents that completed both waves of the survey. Massachusetts serves as a control. ${ }^{11}$ These dependent variables are derived from the following questions that measure the attitudes and behaviors that will likely drive the emergence decision and may be affected by the adoption of the clean election law:

1. "Please rate your personal attraction to a career in your state legislature."

2. "Did you run for state representative in [the last election]?" and "If you did not run for state representative in [the last election], did you at least consider running in that election?"

3. "To what extent do the below factors discourage your running for State Representative?The need to raise money."

4. "Please rate your qualities as a potential candidate for State Representative-Ability to raise money to fund your own campaign."

This analysis relies upon the quasi-experimental nature of the CEPF and assumes that the adoption

\footnotetext{
${ }^{7}$ The Candidate Emergence and Public Financing of Elections Dataset (CEPF) also sample PCs in Rhode Island. However, those respondents were not used in this analysis, or La Raja and Wiltse's (2015b), since it does not share the same qualities as a control that Massachusetts does.

${ }^{8}$ Though these numbers may seem low on their face, Massachusetts has a very professionalized legislature with a low house membership turnover of $11 \%$ in 2008; while Connecticut's turnover was $15 \%$. In this light, only a fraction of PCs in the survey would be able to contemplate a run without the possibility of facing an incumbent of the same party, thus driving down their likelihood of making a run.

${ }^{9}$ The most important differences are legislative pay, staffing, and degree of professionalization. See La Raja and Wiltse $2015 \mathrm{a}$ and $2015 \mathrm{~b}$ for a more detailed description of the sample. ${ }^{10}$ One unfortunate similarity between the states for the purposes of this analysis is the dominance of the Democratic Party. The number of female PCs that identify as Republicans is 34 in Connecticut and 15 in Massachusetts. This renders statistical inferences between women of the two parties nearly impossible.

${ }^{11}$ Descriptive statistics of each variable are provided in the appendix.
} 
of the CEP in Connecticut is a "treatment." The waves of the survey were conducted in April of 2007 and 2009. The CEP was implemented during the 2008 election cycle. The ultimate test of the effects of clean election law on emergence is found in the second question: the actual consideration of a run for state legislature. On this question, the treatment is unambiguous as respondents are being asked about past behavior. There either was public money available when the respondent was forming their decision to run (t2), or there was not (t1). In the remaining questions, there is the possibility that the effects of the treatment may vary slightly between respondents since they are not being explicitly prompted to answer based upon their present or past behaviors. For example, it is likely that some Connecticut respondents in the first wave knew of coming reforms and factored that into their answers. The resulting bias would be that of a non-finding. Regardless, the fact that a wellinformed PC may have partially considered the coming reforms would result in a partial treatment, as these PCs' information would be updated in the second wave only then having observed the actual implementation of the law.

This analysis is also based on the assumption that the adoption of public subsidies in Connecticut, our treatment, is the unique factor between the waves of the survey that affect the "C" term. It also assumed that the "P" term can be adequately controlled for through the inclusion of time variant controls in the regressions. Political and strategic factors, such as holding elective office, PC assessments of the probability of winning the primary, incumbents being of the same party, and political recruitment by parties and other political or civil society groups, are also controlled for. While it is conceivable there could be other factors driving the P-term in Connecticut only, there were no observable changes in district boundaries or intervening political scandals that would set the state apart from Massachusetts between the two survey waves. Other time-variant factors associated with emergence, respondent income and the impact of family costs associated with a run, are included as control variables.

\section{RESULTS}

The results for the "base models" of ambitionthe respondents' formation of interest in a legislative career and their consideration of running for office in 2006 - are presented in Table 3. Simultaneous OLS estimates were obtained for men and women separately. ${ }^{12}$ The chi-square values of significance tests between the coefficients are also presented to test for differences between the coefficients of the two subgroups. While the similarities between the determinants of women and men's nascent political ambition are clear, there is evidence that some aspects of emergence are in fact gendered as the extant literature suggested.

The formation of interest in a state legislative career is structured rather similarly between the genders. A PC's estimated probability of winning the primary was associated with greater interest amongst men and women. However, being of the same party as the incumbent had little effect as ambition can certainly develop well before a strategic opportunity to run presents itself (i.e., an open seat). Other similarities between the genders were apparent. Both groups responded positively to encouragement from nonpolitical entities such as family, neighbors, and coworkers. Moreover, concerns about family costs and age weigh heavily on both men's and women's interest in elective office. While these coefficients are seemingly higher for women, those differences fail to reach statistical significance in tests between the coefficients. One distinction worth noting is that the coefficient for party contacts with female PCs is both statistically significant and negatively signed, suggesting that efforts by the parties are at best ineffectual, or perhaps even detrimental, in developing women's political ambition in this formative stage. Two non-significant terms must be noted. First, a PC's sense of discouragement about raising campaign funds makes no difference in the interest phase of emergence. Second, an interaction term between Connecticut and the discouragement a PC feels from raising money fails to reach statistical significance, suggesting that there are no substantial differences between the states prior to Connecticut's clean election law.

Differences between the genders are more apparent in the estimates of a PC's consideration of a run in 2006. In theoretical terms, it is in this phase of the emergence calculus where we would expect

\footnotetext{
${ }^{12}$ The results were very similar between ordinary least squares (OLS) and ologit models, therefore OLS are reported for ease of interpretation.
} 
Table 3. OlS Regression of Interest in State Legislative Career and Consideration of Candidacy, 2007

\begin{tabular}{|c|c|c|c|c|c|c|}
\hline & \multicolumn{2}{|c|}{ Interest in career } & \multirow[b]{2}{*}{$\begin{array}{c}\text { Chi-square } \\
\text { diff. of coefs. }\end{array}$} & \multicolumn{3}{|c|}{ Consideration of candidacy } \\
\hline & $\begin{array}{c}\text { Women } \\
\mathrm{b} / \mathrm{se}\end{array}$ & $\begin{array}{l}\text { Men } \\
\text { b/se }\end{array}$ & & $\begin{array}{c}\text { Women } \\
\mathrm{b} / \mathrm{se}\end{array}$ & $\begin{array}{l}\text { Men } \\
\text { b/se }\end{array}$ & $\begin{array}{l}\text { Chi-square } \\
\text { diff. of coefs }\end{array}$ \\
\hline Win nomination & $\begin{array}{c}0.532 * \\
(0.292)\end{array}$ & $\begin{array}{c}0.348^{*} \\
(0.185)\end{array}$ & 0.29 & $\begin{array}{l}0.073 \\
(0.104)\end{array}$ & $\begin{array}{r}0.318 * * * \\
(0.062)\end{array}$ & $4.71 * *$ \\
\hline Same party as incumbent & $\begin{array}{l}0.009 \\
(0.223)\end{array}$ & $\begin{array}{l}0.193 \\
(0.155)\end{array}$ & 0.46 & $\begin{array}{r}-0.167 * * \\
(0.076)\end{array}$ & $\begin{array}{r}-0.122 * * \\
(0.052)\end{array}$ & 0.28 \\
\hline Income & $\begin{array}{r}-0.100 \\
(0.111)\end{array}$ & $\begin{array}{r}-0.146^{*} \\
(0.081)\end{array}$ & 0.13 & $\begin{array}{r}0.109 * * * \\
(0.040)\end{array}$ & $\begin{array}{r}-0.006 \\
\quad(0.027)\end{array}$ & $4.80 * *$ \\
\hline Current office holder & $\begin{array}{l}0.096 \\
(0.236)\end{array}$ & $\begin{array}{l}0.298 \\
(0.193)\end{array}$ & 0.46 & $\begin{array}{l}0.107 \\
(0.086)\end{array}$ & $\begin{array}{l}0.114^{*} \\
(0.066)\end{array}$ & 0.01 \\
\hline Recruitment by party org. & $\begin{array}{l}-0.199^{*} \\
\quad(0.120)\end{array}$ & $\begin{array}{l}0.089 \\
(0.064)\end{array}$ & $4.52 * *$ & $\begin{array}{r}0.130 * * * \\
(0.042)\end{array}$ & $\begin{array}{r}0.057 * * \\
(0.022)\end{array}$ & 1.71 \\
\hline Recruitment by civil society org. & $\begin{array}{l}0.179 \\
(0.164)\end{array}$ & $\begin{array}{l}0.060 \\
(0.107)\end{array}$ & 0.52 & $\begin{array}{l}0.022 \\
(0.056)\end{array}$ & $\begin{array}{c}0.078^{*} \\
(0.035)\end{array}$ & 0.56 \\
\hline Recruitment by non-political actor & $\begin{array}{r}0.350 * * * \\
(0.097)\end{array}$ & $\begin{array}{r}0.192 * * \\
(0.068)\end{array}$ & 1.94 & $\begin{array}{r}0.083^{* *} \\
(0.035)\end{array}$ & $\begin{array}{l}0.026 \\
(0.023)\end{array}$ & 1.57 \\
\hline Family costs & $\begin{array}{c}-0.217 * * * \\
(0.055)\end{array}$ & $\begin{array}{c}-0.125 * * * \\
(0.036)\end{array}$ & 1.98 & $\begin{array}{r}-0.032 \\
\quad(0.020)\end{array}$ & $\begin{array}{l}-0.009 \\
\quad(0.012)\end{array}$ & 1.05 \\
\hline Discouraged by negative ads & $\begin{array}{l}0.084 \\
(0.097)\end{array}$ & $\begin{array}{l}0.069 \\
(0.065)\end{array}$ & 0.02 & $\begin{array}{l}0.024 \\
(0.034)\end{array}$ & $\begin{array}{r}0.050 * * \\
(0.021)\end{array}$ & 0.50 \\
\hline Discouraged by raising money & $\begin{array}{l}0.196 \\
(0.128)\end{array}$ & $\begin{array}{l}-0.069 \\
(0.076)\end{array}$ & 3.35 & $\begin{array}{l}-0.007 \\
\quad(0.047)\end{array}$ & $\begin{array}{l}0.023 \\
(0.026)\end{array}$ & 0.48 \\
\hline District partisanship favors PC & $\begin{array}{l}-0.025 \\
\quad(0.073)\end{array}$ & $\begin{array}{r}-0.018 \\
\quad(0.052)\end{array}$ & 0.01 & $\begin{array}{l}0.015 \\
(0.025)\end{array}$ & $\begin{array}{l}0.014 \\
(0.017)\end{array}$ & 0.00 \\
\hline Age & $\begin{array}{c}-0.363 * * * \\
(0.088)\end{array}$ & $\begin{array}{c}-0.282 * * * \\
(0.049)\end{array}$ & 0.58 & $\begin{array}{r}-0.020 \\
(0.030)\end{array}$ & $\begin{array}{r}-0.023 \\
\quad(0.017)\end{array}$ & 0.01 \\
\hline Connecticut & $\begin{array}{l}0.552 \\
(0.542)\end{array}$ & $\begin{array}{l}0.118 \\
(0.344)\end{array}$ & 0.42 & $\begin{array}{l}-0.075 \\
\quad(0.198)\end{array}$ & $\begin{array}{r}0.232 * * \\
(0.116)\end{array}$ & 1.88 \\
\hline $\mathrm{CT} \mathrm{x}$ discouraged raising money & $\begin{array}{r}-0.212 \\
\quad(0.175)\end{array}$ & $\begin{array}{l}0.022 \\
(0.119)\end{array}$ & 1.17 & $\begin{array}{l}0.026 \\
(0.062)\end{array}$ & $\begin{array}{r}-0.069 \\
(0.040)\end{array}$ & 1.78 \\
\hline Constant & $\begin{array}{r}4.222 * * * \\
(0.706)\end{array}$ & $\begin{array}{r}4.263 * * * \\
(0.462)\end{array}$ & & $\begin{array}{r}1.400 * * * \\
(0.256)\end{array}$ & $\begin{array}{r}0.837 * * * \\
(0.155)\end{array}$ & \\
\hline Number of cases & 159 & 353 & & 143 & 329 & \\
\hline Adjusted $r$-square & 0.3234 & 0.2139 & & 0.2606 & 0.2441 & \\
\hline
\end{tabular}

$* p|t|<.10$ two-tailed; $* * p|t|<.05$ two-tailed; $* * * p|t|<.01$ two-tailed.

OLS, ordinary least squares.

short-term strategic concerns and costs to be paramount, as the PC is weighing the possibility of an immediate candidacy (Maestas et al. 2006). For male PCs, the presence of an incumbent of their own party and their sense of electoral security were both substantively and statistically significant. For women, the effects of those strategic factors associated with the P-term were mixed. The presence of an incumbent of the same party suppressed the candidacy of female PCs; however, their estimated probability of winning the primary was not significant. Another sharp distinction between the groups was the effect of income. As female PC income increased, their serious consideration of candidacy went down. No such relationship was found for male PCs. While not a cost of campaigning per se, the potential effects on their careers outside of pol- itics is certainly part of the cost calculation of women PCs. Active encouragement from outside actors was also important in the emergence decision. Both men and women responded positively to contacts from party groups. Civil society group recruitment was significant for male PCs, while encouragement from non-political actors was important for women, lending some empirical support of Carroll and Sanbonmatsu's (2013) claim that the emergence is a "relationally embedded decision" for women.

Finally, as in the legislative career interest model, the key controls of money discouraging a candidacy and the interaction between discouragement and Connecticut failed to attain statistical significance. Put differently, concerns about fundraising do not seem to be all that important in the C-term of the emergence model for PCs of any gender. 
To assess the possibility of the Connecticut reforms prompting women into candidacies for state legislature or affecting their attitudes on fundraising, we can take advantage of the panel data. To this end, several pairs of OLS regressions were estimated splitting the sample between men and women on key dependent variables: consideration of a candidacy in the last election cycle (Table 4), their confidence in being able to raise sufficient money for a candidacy, and whether money discouraged their consideration of a run (both presented in Table 5). The regressions include only those respondents who completed both waves of the survey, allowing us to observe changes within individuals. Each of these dependent variables model behaviors or attitudes that may indicate a change in a PC's emergence calculus. Should the interaction term of Connecticut and the year 2009 be significant and positive amongst women and not men (or the coefficients be significantly stronger for women), it would suggest that the implementation of clean elections may have

Table 4. Pooled OlS Regression of Considering a State Legislative Candidacy, 2007 and 2009

\begin{tabular}{|c|c|c|c|}
\hline & $\begin{array}{c}\text { Women } \\
\text { b/se }\end{array}$ & $\begin{array}{l}\text { Men } \\
b / s e\end{array}$ & $\begin{array}{l}\text { Chi-square } \\
\text { diff. of coefs. }\end{array}$ \\
\hline Win nomination & $\begin{array}{r}0.048 * * \\
(0.022)\end{array}$ & $\begin{array}{r}0.082 * * * \\
(0.016)\end{array}$ & 1.91 \\
\hline $\begin{array}{l}\text { Same party as } \\
\text { incumbent }\end{array}$ & $\begin{array}{c}-0.097 \\
(0.061)\end{array}$ & $\begin{array}{r}-0.076 \\
(0.047)\end{array}$ & 0.10 \\
\hline Income & $\begin{array}{c}-0.121 * * * \\
(0.033)\end{array}$ & $\begin{array}{l}-0.013 \\
\quad(0.027)\end{array}$ & $7.40 * *$ \\
\hline Current office holder & $\begin{array}{l}0.011 \\
(0.068)\end{array}$ & $\begin{array}{l}0.009 \\
(0.063)\end{array}$ & 0.00 \\
\hline $\begin{array}{l}\text { Recruitment by } \\
\text { party org. }\end{array}$ & $\begin{array}{r}0.156^{* * * *} \\
(0.034)\end{array}$ & $\begin{array}{r}0.072^{* * * *} \\
(0.022)\end{array}$ & 1.78 \\
\hline $\begin{array}{l}\text { Recruitment by civil } \\
\text { society org. }\end{array}$ & $\begin{array}{l}-0.274 \\
\quad(0.253)\end{array}$ & $\begin{array}{l}0.264 \\
(0.187)\end{array}$ & 1.62 \\
\hline $\begin{array}{l}\text { Recruitment by } \\
\text { non-political actor }\end{array}$ & $\begin{array}{r}0.076 * * * \\
(0.029)\end{array}$ & $\begin{array}{r}0.041 * * \\
(0.020)\end{array}$ & 0.76 \\
\hline Family costs & $\begin{array}{l}0.001 \\
(0.015)\end{array}$ & $\begin{array}{l}-0.013 \\
\quad(0.012)\end{array}$ & 0.73 \\
\hline 2009 & $\begin{array}{r}-0.053 \\
(0.087)\end{array}$ & $\begin{array}{r}0.112 * * \\
(0.056)\end{array}$ & $3.00 *$ \\
\hline Connecticut & $\begin{array}{r}-0.154^{*} \\
(0.083)\end{array}$ & $\begin{array}{l}0.013 \\
(0.061)\end{array}$ & $3.12 *$ \\
\hline 2009 x Connecticut & $\begin{array}{c}0.194^{*} \\
(0.114)\end{array}$ & $\begin{array}{r}-0.112 \\
\quad(0.087)\end{array}$ & $5.00 * *$ \\
\hline Constant & $\begin{array}{r}1.288^{* * * *} \\
(0.138)\end{array}$ & $\begin{array}{r}0.980 * * * \\
(0.129)\end{array}$ & \\
\hline Number of cases & 149 & 371 & \\
\hline Adjusted $r$-square & 0.2882 & 0.1953 & \\
\hline
\end{tabular}

Analysis includes respondents who completed both waves of the survey ${ }^{*} p|t|<.10$ two-tailed; $* * p|t|<.05$ two-tailed; *** $p|t|<.01$ two-tailed. OLS, ordinary least squares. roused ambition or changed their attitudes on fundraising disproportionately amongst women.

The panel results were decidedly mixed. Only in the first question-whether the PC considered a run for state legislature-was there an indication of changed behavior. The term was signed in the hypothesized direction and statistically significant. Moreover, the differences between the coefficients for women and men also reached statistical significance. However, PC attitudes on their abilities to raise money or whether money discourages a candidacy are seemingly unmoved by public subsidy for either women or men. In summation, though there was a small uptick in women emerging as candidates to the state legislature in Connecticut after the reforms, considerations of campaign cost were largely absent in the C-term of the emergence calculus for either men or women before or after the CEP. This raises serious questions about the efficacy of the CEP in closing the gender gap in the state legislature.

Where the models are particularly instructive are in the significant factors that fall outside the bounds of campaign finance law-strategic concerns expressed in the P-term, and the role of parties and civil society groups encouraging consideration of candidacies. In the candidacy model (Table 4), the determinants of emergence for women and male PCs are very similar. The only distinction (apart from the previously mentioned uptick amongst women in Connecticut) between male and female PCs is the effect of income. The all-important strategic factor of the likelihood of a primary win was of clear importance for all PCs, as were the contacts of encouragement from parties and non-political entities. Where gender differences emerge are on attitudes about fundraising (Table 5). Here we see that the source of recruitment is critical in shaping the attitudes of female PCs, with statistically significant differences between the coefficients in all types of recruitment contacts. Party contacts are strongly correlated with confidence in fundraising for men, but not for women, whereas civil society group recruitment instills confidence in women, but not in men. Finally, while both genders are given a sense of campaign financial security by recruitment from non-political actors, that encouragement is significantly stronger for female PCs. Again, this gives potent empirical support, and nuance, to the prospect that women's emergence decisions are more "relationally embedded" than for men (Carroll and Sanbonmatsu 2013). 
Table 5. Pooled OlS Regression of Attitudes Towards Fundraising, 2007 and 2009

\begin{tabular}{|c|c|c|c|c|c|c|}
\hline & \multicolumn{3}{|c|}{ Able to raise money } & \multicolumn{3}{|c|}{ Money discouraging candidacy } \\
\hline & $\begin{array}{l}\text { Women } \\
\text { b/se }\end{array}$ & $\begin{array}{l}\text { Men } \\
\text { b/se }\end{array}$ & $\begin{array}{c}\text { Chi-square } \\
\text { diff. of coefs. }\end{array}$ & $\begin{array}{c}\text { Women } \\
\text { b/se }\end{array}$ & $\begin{array}{l}\text { Men } \\
\text { b/se }\end{array}$ & $\begin{array}{l}\text { Chi-square } \\
\text { diff. of coefs. }\end{array}$ \\
\hline Win nomination & $\begin{array}{r}0.151 * * \\
(0.060)\end{array}$ & $\begin{array}{r}0.246 * * * \\
(0.040)\end{array}$ & 1.73 & $\begin{array}{l}0.074 \\
(0.055)\end{array}$ & $\begin{array}{r}-0.077 * \\
(0.037)\end{array}$ & $5.55 * *$ \\
\hline Same party as incumbent & $\begin{array}{r}0.407 * * \\
(0.165)\end{array}$ & $\begin{array}{r}0.497 * * * \\
(0.116)\end{array}$ & 0.20 & $\begin{array}{l}0.110 \\
(0.149)\end{array}$ & $\begin{array}{c}-0.128 \\
(0.109)\end{array}$ & 1.73 \\
\hline Income & $\begin{array}{r}0.435 * * * \\
(0.089)\end{array}$ & $\begin{array}{l}0.063 \\
(0.067)\end{array}$ & $11.88 * * *$ & $\begin{array}{r}-0.236^{* *} \\
(0.081)\end{array}$ & $\begin{array}{l}0.043 \\
(0.062)\end{array}$ & $7.23 * * *$ \\
\hline Current office holder & $\begin{array}{r}0.337 * \\
(0.185)\end{array}$ & $\begin{array}{l}0.057 \\
(0.155)\end{array}$ & 1.54 & $\begin{array}{l}0.153 \\
(0.167)\end{array}$ & $\begin{array}{l}0.074 \\
(0.145)\end{array}$ & 0.14 \\
\hline Recruitment by party org. & $\begin{array}{l}0.075 \\
(0.093)\end{array}$ & $\begin{array}{r}0.250 * * * \\
(0.054)\end{array}$ & $3.67 *$ & $\begin{array}{r}-0.155 \\
(0.084)\end{array}$ & $\begin{array}{r}-0.157 * * \\
(0.051)\end{array}$ & 0.00 \\
\hline Recruitment by civil society org. & $\begin{array}{c}1.194 * \\
(0.736)\end{array}$ & $\begin{array}{l}0.262 \\
(0.476)\end{array}$ & $3.63 *$ & $\begin{array}{r}-0.446 \\
\quad(0.665)\end{array}$ & $\begin{array}{l}0.289 \\
(0.447)\end{array}$ & 1.60 \\
\hline Recruitment by non-political actor & $\begin{array}{r}0.294 * * * \\
(0.079)\end{array}$ & $\begin{array}{r}0.131 * * * \\
(0.049)\end{array}$ & $3.54 *$ & $\begin{array}{r}-0.221 * * \\
(0.071)\end{array}$ & $\begin{array}{r}-0.099^{*} \\
\quad(0.046)\end{array}$ & 2.08 \\
\hline Family costs & $\begin{array}{l}0.042 \\
(0.041)\end{array}$ & $\begin{array}{l}0.033 \\
(0.029)\end{array}$ & 0.03 & $\begin{array}{r}0.191 * * * \\
(0.036)\end{array}$ & $\begin{array}{r}0.130 * * * \\
(0.027)\end{array}$ & 1.90 \\
\hline 2009 & $\begin{array}{l}0.337 \\
(0.240)\end{array}$ & $\begin{array}{r}-0.047 \\
(0.137)\end{array}$ & 2.06 & $\begin{array}{r}-0.100 \\
\quad(0.216)\end{array}$ & $\begin{array}{r}-0.058 \\
\quad(0.128)\end{array}$ & 0.03 \\
\hline Connecticut & $\begin{array}{l}-0.025 \\
(0.225)\end{array}$ & $\begin{array}{r}-0.034 \\
(0.151)\end{array}$ & 0.00 & $\begin{array}{l}0.208 \\
(0.207)\end{array}$ & $\begin{array}{l}0.028 \\
(0.141)\end{array}$ & 0.54 \\
\hline 2009 x Connecticut & $\begin{array}{r}-0.237 \\
(0.317)\end{array}$ & $\begin{array}{l}0.079 \\
(0.214)\end{array}$ & 0.73 & $\begin{array}{l}0.135 \\
(0.286)\end{array}$ & $\begin{array}{r}-0.297 \\
(0.199)\end{array}$ & 1.63 \\
\hline Constant & $\begin{array}{l}0.380 \\
(0.395)\end{array}$ & $\begin{array}{r}1 \\
(0.314)\end{array}$ & $4 * * *$ & $\begin{array}{r}2.321 * * * \\
(0.357)\end{array}$ & $\begin{array}{r}2.445 * * * \\
(0.293)\end{array}$ & \\
\hline Number of cases & 167 & 398 & & 167 & 403 & \\
\hline Adjusted $r$-square & 0.3151 & 0.2135 & & 0.2558 & 0.129 & \\
\hline
\end{tabular}

Analysis includes respondents who completed both waves of the survey.

$* p|t|<.10$ two-tailed; $* * p|t|<.05$ two-tailed; $* * * p|t|<.01$ two-tailed.

OLS, ordinary least squares.

\section{DISCUSSION}

These results suggest that some reformers' hopes that CEP would encourage broader participation may have been realized, but that there are very clear limits to clean election laws in regards to their effectiveness in changing women's attitudes on fundraising and their ambitions towards elective office. These results also suggest that the emergence decision for state legislative candidacy is gendered to a fair degree. The process of building nascent ambition is quite similar between female and male PCs. However, as the decision of a PC to throw her hat in the ring becomes immanent, the actions of political parties and civil society organizations will be most influential in the encouragement of candidacy and shaping the attitudes of campaign fundraising. It is also the point where the emergence calculus begins to take on important differences between the genders.

These results speak to the importance that political parties, civil society groups, and non-political actors understand and adapt to the gendered nature of the emergence calculus of PCs to the state legislature. There is evidence that both PCs' attitudes on political money and the influence of these groups in shaping these attitudes are not gender neutral. Parties, civil society groups, and non-political actors provide critical means of recruitment for PCs in their consideration of running for office. However, their recruitment has differential effects on PCs' confidence in raising money for their potential campaigns. Party recruitment bolsters men's confidence in fundraising, whereas it shows no effect on women. Conversely, encouragement from civil society instills the same confidence amongst women, but not for men. While the data do not allow us to identify which interest groups are making these contacts, groups like Emily's List were given as specific examples in the questionnaire, and it is reasonable to assume that they are amongst these civil society organizations making up for many of the shortcomings of the political parties. If a goal of reform is more women running for office, the subsidization of election costs is only a small part of the solution. These results suggest 
that progress towards gender parity in state legislatures is more likely to be made if the relational aspects of the emergence decision are enhanced through viable civil society organizations, and that political parties take steps to improve their outreach towards women PCs.

In many regards, the introduction of full public subsidies has been underwhelming in terms of creating systemic changes to the structure of politics in the states that have introduced clean elections. However, reformers can take heart that some progress towards gender equity in candidate emergence could join the list of other successes of clean elections such as fewer uncontested elections, decreases in the amount of time spent fundraising, and lowering the reliance upon private donors and special interests. These results should remind us, though, that encouraging broader participation of female candidates may require more fundamental systemic changes to the system due to the complex nature of the problem, as it is also rooted in deeper institutional features such as single-member districts, nomination procedures, political party recruitment, the role of civil society organizations, to name but a few. None of these things can be addressed through simple subsidies, be they the partial subsidies as were found in Minnesota or Wisconsin, or the clean election systems of Arizona, Maine, or Connecticut.

\section{REFERENCES}

Berry, William D., Michael B. Berkman, and Stuart Schneiderman. 2000. "Legislative Professionalism and Incumbent Reelection: The Development of Institutional Boundaries." American Political Science Review 94(4): 859-74.

Bianco, William T. 1984. "Strategic Decisions on Candidacy in U.S. Congressional Districts.” Legislative Studies Quarterly 9(2): 351-64.

Black, Gordon S. 1972. "A Theory of Political Ambition: Career Choices and the Role of Structural Incentives." American Political Science Review 66(1): 144-59.

Burrell, Barbara. 1994. A Woman's Place Is in the House: Campaigning for Congress in the Feminist Era. Ann Arbor: University of Michagan Press.

Carroll, Susan and Kira Sanbonmatsu. 2013. More Women Can Run: Gender and Pathways to the State Legislatures. New York: Oxford.

Donnay, Patrick D. and Graham P. Ramsden. 1995. "Public Financing of Legislative Elections: Lessons from Minnesota." Legislative Studies Quarterly 20(3): 351-64.

Dowling, Conor. 2011. "Public Financing and Candidate Participation in Gubernatorial Elections." in Public Financing in American Elections, ed. Costas Panagopoulos. Philadelphia: Temple Univeristy Press, 184-224.

Fox, Richard L. and Jennifer L. Lawless. 2010. "If Only They'd Ask: Gender, Recruitment, and Political Ambition." Journal of Politics 72(2): 310-326.

Francia, Peter L. and Paul S. Herrnson. 2003. "The Impact of Public Finance Laws on Fundraising in State Legislative Elections." American Politics Research 31(5): 520-39.

Fulton, Sarah A., Cherie D. Maestas, L. Sandy Maisel, and Walter J. Stone. 2006. "The Sense of a Woman: Gender, Ambition, and the Decision to Run for Congress." Political Research Quarterly 59(2): 235-248.

Hamm, Keith E. and Robert E. Hogan. 2008. "Campaign Finance Laws and Candidacy Decisions in State Legislative Elections.” Political Research Quarterly 61(3): 458-67.

Jackman, Robert W. and Ross A. Miller. 1996. "A Renaissance of Political Culture?" American Journal of Political Science 40(3): 632-59.

Jacobson, Gary C. and Samuel Kernell. 1981. Strategy and Choice in Congressional Elections. New Haven: Yale University Press.

Jenkins, Shannon. 2007. “A Woman's Work is Never Done? Fundraising Perception among Female State Legislative Candidates." Political Research Quarterly 60(2): 230-239.

Krasno, Jonathan S. and Donald Philip Green. 1988. "Preempting Quality Challengers in House Elections." Journal of Politics 50(4): 920.

La Raja, Raymond J. and David L. Wiltse. 2015a. "The Candidate Emergence and Public Financing of Elections Dataset." Available at <http://dataverse.org>. Amherst, MA: University of Massachusetts Amherst.

La Raja, Raymond J. and David L. Wiltse. 2015b. "Money That Draws No Interest: Public Financing of Legislative Elections and Candidate Emergence." Election Law Journal 14(4): 392-410.

Lawless, Jennifer L. and Richard L. Fox. 2005. It Takes a Candidate: Why Women Don't Run for Office. New York: Cambridge University Press.

Lawless, Jennifer L. and Richard L. Fox. 2010. It Still Takes a Candidate: Why Women Don't Run for Office. New York: Cambridge University Press.

Lawless, Jennifer, L and Kathryn Pearson. 2008. "The Primary Reason for Women's Underrepresentation? Reevaluating the Conventional Wisdom." Journal of Politics 70(1): 67-82.

Lazarus, Jeffrey. 2008. "Incumbent Vulnerability and Challenger Entry in Statewide Elections." American Politics Research 36(1): 108-29.

Maestas, Cherie D., Sarah Fulton, L. Sandy Maisel, and Walter J. Stone. 2006. "When to Risk It? Institutions, Ambitions, and the Decision to Run for the U.S. House." American Political Science Review 100(02): 195-208.

Maisel, L. Sandy and Walter J. Stone. 2003. "The NotSo-Simple Calculus of Winning: Potential U.S. House Candidates' Nomination and General Election Prospects." Journal of Politics 65(4): 951-77.

Maisel, L. Sandy and Walter J. Stone. 1997. "Determinants of Candidate Emergence in U.S. House Elections: An Exploratory Study." Legislative Studies Quarterly 22(1): 79-96.

Malhotra, Neil. 2008. "The Impact of Public Financing on Electoral Competition: Evidence from Arizona and Maine." State Politics and Policy Quarterly 8(3):263-81. 
Mayer, Kenneth R., Timothy Wener, and Amanda Williams. 2006. "Do Public Funding Programs Enhance Electoral Competition?" in The Marketplace of Democracy: Electoral Competition and American Politics, ed. Michael McDonald and John Curtis Samples. Washington, DC: Cato Institute: Brookings Institution Press.

Mayer, Kenneth R. and John M. Wood. 1995. "The Impact of Public Financing on Electoral Competitiveness: Evidence from Wisconsin, 1964-1990." Legislative Studies Quarterly 20(1): 69-88.

Mayer, Kenneth R. 2013. "Public Election Funding: An Assessment of What We Would Like to Know." The Forum: A Journal of Applied Research in Contemporary Politics 11(3): 365-384.

Miller, Michael Gerald. 2013. Subsidizing Democracy: How Public Funding Changes Elections and How It Can Work in the Future. Ithaca: Cornell University Press.

Mithchell, Nathan K. 2014. "Ballot Access Rules and the Entry of Women Candidates in the State Legislative Primaries." Journal of Power, Politics, and Governance 2(3\&4): $1-25$.

Mithchell, Nathan K. and Billy Monroe. 2014. "Where Do Women Run? A Case for the Study of "Women Friendly Districts' in State Legislative Primaries." Journal of Power, Politics, and Governance 2(4): 37-57.

Panagopoulos, Costas and Donald P. Green. 2008. "Field Experiments Testing the Impact of Radio Advertisments on Electoral Competition." American Journal of Political Science 52(1): 156-168.
Pont, Ryan and Bradley R. Pollock. 2014. "Last Rites for Clean Elections.” Arizona Law Review 56(4): 1243-1256.

Schneider, Deborah E. 2000. “As Goes Maine? The 1996 Maine Clean Election Act: Innovations and Implications for Future Campaign Finance Reforms at the State and Federal Level." Washington University Journal of Law and Policy 2(1): 627-664.

Spencer, Andrew. 2012. "Cleaning Elections." Arizona Law Review 54: 277-309.

Thompson, Joel, Gary Moncrief, and Keith Hamm. 1998. "Gender, Candidate Attirbutes, and Campaign Contributions." in Campaign Finance in State Legislative Elections, ed. Joel Thompson and Gary Moncrief. Washington, DC: CQ Quarterly, 117-138.

Werner, Timothy and Kenneth R. Mayer. 2007. "Public Election Funding, Competition, and Candidate Gender." PS: Political Science and Politics 40(4): 661-67.

Windett, Jason Harold. 2011. "State Effects and the Emergence and Success of Female Gubernatorial Candidates." State Politics and Policy Quarterly 11(4): 460-482.

Address correspondence to: David Wiltse South Dakota State University West Hall 220 Brookings, SD 57007

E-mail: david.wiltse@sdstate.edu

\section{APPENDIX: SUMMARY STATISTICS OF VARIABLES USED}

Table A1. Wave 1: April 2007

\begin{tabular}{|c|c|c|c|c|c|}
\hline Variable & Obs. & Mean & Std. Dev. & Min. & Max. \\
\hline $\begin{array}{l}\text { Interest in state leg. } \\
\text { candidacy }\end{array}$ & 598 & 1.196 & 0.445 & 1 & 3 \\
\hline $\begin{array}{l}\text { Interest in state leg. } \\
\text { career }\end{array}$ & 646 & 2.839 & 1.291 & 1 & 5 \\
\hline $\begin{array}{l}\text { Probability of winning } \\
\text { nomination }\end{array}$ & 650 & 0.393 & 0.375 & 0.01 & 0.99 \\
\hline Same party as incumbent & 663 & 0.463 & 0.499 & 0 & 1 \\
\hline Income & 623 & 2.567 & 0.781 & 1 & 4 \\
\hline Local office holder & 655 & 0.864 & 0.343 & 0 & 1 \\
\hline $\begin{array}{l}\text { Recruitment by party } \\
\text { officials or leaders }\end{array}$ & 617 & 0.652 & 1.081 & 0 & 4 \\
\hline $\begin{array}{l}\text { Recruitment by civil } \\
\text { society organization }\end{array}$ & 632 & 0.427 & 0.717 & 0 & 3 \\
\hline $\begin{array}{l}\text { Recruitment by } \\
\text { non-political actor }\end{array}$ & 632 & 0.940 & 1.160 & 0 & 3 \\
\hline Perceived family costs & 643 & 4.703 & 1.874 & 2 & 8 \\
\hline $\begin{array}{l}\text { Discouraged by negative } \\
\text { ads/campaign }\end{array}$ & 641 & 2.073 & 1.062 & 1 & 4 \\
\hline $\begin{array}{l}\text { Discouraged by raising } \\
\text { money }\end{array}$ & 647 & 2.760 & 1.056 & 1 & 4 \\
\hline $\begin{array}{l}\text { District partisanship } \\
\quad \text { favors } R\end{array}$ & 642 & 3.167 & 1.414 & 0 & 5 \\
\hline Age & 663 & 4.041 & 1.239 & 1 & 6 \\
\hline
\end{tabular}

Table A2. Wave 2: April 2009

\begin{tabular}{|c|c|c|c|c|c|}
\hline Variable & Obs. & Mean & Std. Dev. & Min. & Max. \\
\hline $\begin{array}{l}\text { Interest in state leg. } \\
\text { candidacy }\end{array}$ & 318 & 1.208 & 0.464 & 1 & 3 \\
\hline $\begin{array}{l}\text { Interest in state leg. } \\
\text { career }\end{array}$ & 340 & 2.550 & 1.272 & 1 & 5 \\
\hline $\begin{array}{l}\text { Probability of winning } \\
\text { nomination }\end{array}$ & 321 & 0.458 & 0.380 & 0.01 & 0.99 \\
\hline Same party as incumbent & 322 & 0.217 & 0.413 & 0 & 1 \\
\hline Income & 340 & 2.538 & 0.906 & 1 & 4 \\
\hline Local office holder & 352 & 0.722 & 0.449 & 0 & 1 \\
\hline $\begin{array}{l}\text { Recruitment by party } \\
\text { officials or leaders }\end{array}$ & 332 & 0.645 & 1.034 & 0 & 4 \\
\hline $\begin{array}{l}\text { Recruitment by civil } \\
\text { society organization }\end{array}$ & 339 & 0.490 & 0.500 & 0 & 3 \\
\hline $\begin{array}{l}\text { Recruitment by } \\
\text { non-political actor }\end{array}$ & 340 & 0.806 & 1.123 & 0 & 3 \\
\hline Perceived family costs & 346 & 4.650 & 1.910 & 2 & 8 \\
\hline $\begin{array}{l}\text { Discouraged by raising } \\
\text { money }\end{array}$ & 351 & 2.695 & 1.048 & 1 & 4 \\
\hline $\begin{array}{l}\text { Self-assessed ability to } \\
\text { raise money }\end{array}$ & 342 & 3.041 & 1.161 & 1 & 5 \\
\hline
\end{tabular}

